Uragami, A., A. SAKAI, M. NAGAi and T. TAKAHASHI (1989): Survival of cultures cells and somatic embryos of Asparagus officinalis L. cryopreserved by vitrification. Plant Cell Rep. 8: 418-421.

Vasquez, N., K. Salazar, F. Anthony, N. Chabrillange, F. Engelmann and S. Dussert (2005): Variability in response of seeds to liquid nitrogen exposure in wild coffee (Coffea arabica L.). Seed Science and Technology 33: 293-301.
VertuCCI, C. W. (1989): Relationship between thermal transitions and freezing injury in pea and soybean seeds. Plant Physiology 90: 1121-1128.

Walters, C., L. Wheeler and P. C. Stanwood (2004): Longevity of cryogenically stored seeds. Cryobiology 48: 229-244.

YoushenG, C. and O. SzIKLAI (1985): Preliminary study on the germination of Toona sinensis (A. Juss.) Roem. seed from eleven Chinese provenances. Forest Ecology and Management 10: 269-281.

\title{
Identification and Characterization of Microsatellite Markers Useful for Genetic Analysis of Black Spruce (Picea mariana (Mill.) Populations
}

\author{
By S. Dobrzeniecka ${ }^{1)}$, K. K. Nkongolo ${ }^{\left.1,{ }^{*}\right)}$, P. Michael ${ }^{1)}$, S. Wyss $^{1)}$ and M. Mehes ${ }^{1)}$
}

(Received 28 ${ }^{\text {th }}$ April 2008)

\begin{abstract}
Summary
Large - scale isolation of microsatellite and information in any conifer species is limited. Our knowledge of microsatellite in spruce (Picea spp.) is still sketchy. Genomic libraries of $P$. mariana were constructed and screened with $(\mathrm{AC})_{15}$ probes. Over 200 positive clones were found for this dinucleotide and ten were analyzed in details. They were sequenced to confirm the presence of microsatellites and to generate polymerase chain reaction (PCR) primers based on sequences flanking the microsatellites. All sequenced (AC) ${ }_{n}$ clones had repeats of $\mathrm{n}>23$. Primer pairs were designed from seven sequences. These primer pairs along with 15 primer pairs from white spruce (Picea glauca) were tested on individual trees. Seven primer pairs from $P$. mariana and three from $P$. glauca (white spruce) amplified DNA from $P$. mariana and were used for genetic analysis of black spruce populations from uplands (drylands) and lowlands (wetlands). High levels of polymorphism and heterozygosity were observed in all the populations studied. Both highlands and lowlands showed similar levels of genetic variation. The selected microsatellites sequences are being used for genome organization analysis of black spruce.
\end{abstract}

Key words: Picea mariana, black spruce, microsatellites, upland, lowland, polymorphism.

\section{Introduction}

Microsatellites (or SSRs) have in recent years become the marker system of choice in population genetics and linkage analysis, due to their co-dominant nature and

\footnotetext{
$\left.{ }^{1}\right)$ Department of Biology, Laurentian University, Sudbury, Ontario, P3E 2C6, Canada.

*) Corresponding author: K. K. NKONGOLO.

E-Mail: knkongolo@laurentian.ca
}

polymorphism (RAJORA et al., 2001; SCOTTI et al., 2002; GUPTA et al., 2005). The procedures to develop these markers are time - consuming, labour intensive which hinders researchers from isolating such loci (ECHT et al., 1986; Еснт et al., 1996 and Sсотті et al., 2002).

The relatively low frequency of microsatellites in plant genomes presents some technical problems for largescale isolation of microsatellites and information in any particular plant species is limiting. This problem can be overcome by using previously developed microsatellite primers from related species due to the conservation of the flanking sequence (EcHT et al., 1999). This would reduce development costs and provide useful information for comparative linkage relationships between species (ECHT, 1999). To date, there are no reported studies of genetic diversity in Picea mariana (black spruce) populations using microsatellite markers. A limited number of microsatellite DNA markers have been developed for few spruce species, Norway spruce (Picea abies), Sitka spruce (P. sitechensis), and white spruce (P. glauca) (HodGetTs et al., 2001; PFEIFFER et al., 1997; ScotTI et al., 2002; and RAJORA et al., 2001). The main objective of the present study was to develop and characterize microsatellite primers from $P$. mariana genomic DNA libraries. These $P$. mariana derived primers along with heterologous primers from $P$. glauca were used to characterize populations growing in different ecological areas, mainly uplands (drylands) and lowlands (wetlands)

\section{Material and Methods}

\section{Genetic materials}

For the library construction, black spruce needles were collected from individual trees from Petawawa for- 
est Institute (Ontario, Canada). For polymorphism analysis, needles were collected from 270 black spruce trees from nine populations from uplands (drylands) and lowlands (wetlands) located in the Sudbury, Ontario (Canada) region.

\section{DNA extraction, library construction and screening for SSR sequences}

The total cellular DNA from $1 \mathrm{~g}$ of bulk needle samples, as well as, from individual samples was extracted from needle tissue using the method described by NKONGOLO et al. (2005). The partial genomic library enriched for (AC/TG) containing microsatellites was constructed according to a protocol described by HAMILTON et al. (1999) with some modifications. Genomic DNA (10 $\mu \mathrm{g})$ were digested with AluI, EcoRV, Hha I, RsaI, Nhe I, Ssp I. Digested fragments were ligated to the SNX linker according to HAMILTON et al. (1999). Microsatellite enrichment was performed as described by EDWARDS et al. (1996). Eluted DNA was PCR amplified to regenerate double stranded fragments and ligated into pGEMT-Easy vector (Promega) and then cloned into top 10 $E$. coli cells (Invitrogen). Bacteria were plated on X-gal IPTG LB agar plates containing $100 \mathrm{ug} / \mathrm{ml}$ ampicillin. $\mathrm{AC}_{15}$ oligonucleotides were 3 prime end labelled with fluorescein using Amershams 3' end labelling kit and detected by enhanced chemiluminescence according to manufacturer's instructions. Positive colonies were picked and grown in LB broth containing $100 \mathrm{ug} / \mathrm{ml}$ ampicillin. Plasmid DNA was extracted using Qiagen's QIAprep Spin Miniprep kit. Purified DNA from isolated clones with putative microsatellites were sequenced using the ABI Prism 377 automated DNA sequencer (Applied Biosystems, Foster, Calif.).

Based on the sequences containing microsatellites, oligonucleotide PCR primers complementary to the flanking region of the microsatellites were designed and synthesized. They were used for DNA amplification and polymorphism analysis.

\section{PCR amplification, primer optimization, and resolution of microsatellites}

DNA from 270 black spruce trees from nine populations were individually primed with pairs of designed oligonucleotide primers. In addition, 15 microsatellite primers developed from white spruce (Picea glauca) libraries were tested with these $P$. mariana samples. Samples were amplified on a DNA thermal cycler (Perkin-Elmer) as described in NKONGOLO et al. (2005). The PCR protocol for microsatellite analysis was performed as follows: $95^{\circ} \mathrm{C}$ for $5 \mathrm{~min}$. followed by 1 cycle of 2 minutes at $85^{\circ} \mathrm{C}$. This was followed by 42 cycles of $95^{\circ} \mathrm{C}$ for $30 \mathrm{sec} .46 .7^{\circ} \mathrm{C}$ for $1 \mathrm{~min} 30$ sec. and $72^{\circ} \mathrm{C}$ for 30 sec. with a final extension step of $72^{\circ} \mathrm{C}$ for $7 \mathrm{~min}$.

\section{Statistical Analysis}

The presence and absence of bands were scored as 1 or 0 respectively for each individual. The Quantity One software was used for the allele designation by comparing allele bands to the $10 \mathrm{bp}$ ladder. The determination of populations that are in Hardy-Weinberg Equilibrium (HWE) was analyzed with the PowerMarker software version 3.25 (LIU and MusE, 2005). the popgene software version 1.32 (YEH et al., 1997) was used to asses the number of alleles per locus, percentage of polymorphic loci, the observed and expected heterozygosity, and the population differentiation $\left(\mathrm{F}_{\mathrm{ST}}\right)$.

\section{Results and Discussion}

A partial genomic library consisting of a couple hundred positive clones was screened. The sequencing of 20 positive clones identified through screening with AC/TG probes revealed seven informative microsatellites that were registered in the EMBL gene bank under the accessions numbers EF144150, EF144151, EF144152, EF144153, EF144154, EF14455, and EF144156 corresponding to clones 2-4.39, 2-6.11, 2-6.35, 2-7.7, 2-3.25, $2-3.7$, and 2-3.5, respectively (Table 1). Overall two of these sequences were perfect (2-3.5-SP6 and 2-3.25SP6), two imperfect (2-4.39-SP6 and 2-3.7- SP6) and three compound (2-6.635-SP6, 2-7.7-SP6- 2-6.11-SP6) microsatellites (Table 1). Blast searches were performed to identify similarity between the microsatellite from the present study and the sequences in the database. All microsatellite sequences were found to be unique except for the T-7 sequence of the clone 2-7.7 (accession number EF144156). This sequence had 95\% homology with a microsatellite sequence derived from Picea abies registered by SсотTI et al. (2000, unpublished) under the accession number AJ292716. This suggests that some microsatellite sequences are conserved within the genus Picea.

All the seven microsatellites that were isolated from the $(\mathrm{AC})_{15}$ positive clones exhibited $\mathrm{n}$ over 23 repeats (n equals the number of repeats), with the average number of repeats being 25.6. The maximum number of AC repeats was 33 . The microsatellite markers developed in the present study were highly variable for the detection of intra - and interpopulational genetic structure. The seven primer pairs amplified $P$. mariana DNA. The strongest bands were obtained with the primer pairs derived from microsatellite EF144154 (clone 2-3.25_SP6) whose sequence is described in figure 1. Microsatellite primers derived from $P$. glauca (UAPgCT3, PGL-15, and PGL-14) provided also useful genetic information for $P$. mariana populations as they generated each 10 to 11 alleles and polymorphic banding pattern. The information on these microsatellite markers has been published in HoDGETTs et al. (2001) for UAPgCT3 and in RAJORA et al. (2001) for PGL 14 and PGL15. The specific allele sizes for $P$. mariana varied between $206 \mathrm{bp}$ to $292 \mathrm{bp}$ for UAPgCT3, $136 \mathrm{bp}$ to 180 bp for PGL 14, and 182 bp to 270 bp for PGL15.

\section{Genetic diversity in black spruce (Picea mariana) populations}

Microsatellite primer pairs from Picea mariana and $P$. glauca were combined to study the genetic diversity of $P$. mariana populations growing on wetlands (lowlands) and drylands (uplands). They produced bands in the expected range and had low levels of stutter bands when visualized after silver staining. The detailed analysis of $P$. mariana populations revealed high genetic variation 
within each population. The expected heterozygosity $\left(\mathrm{H}_{\mathrm{E}}\right)$ ranged from 0.584 to 0.772 and the observed heterozygosity $\left(\mathrm{H}_{\mathrm{O}}\right)$ from 0.425 to 0.732 (Table 2). Similar results were reported in studies of other spruce species (AMARASINGHE and CARLSON, 2002). But the results presented in the present study revealed much higher level of heterozygosity compared to data reported for Picea asperata populations from Chinese mountains (WANG et al., 2005), and for Jack pine (Pinus banksiana) and red pine (Pinus resinosa) growing in the same Northern Ontario areas (RANGER et al., 2007).

Overall, black spruce ( $P$. mariana) populations growing in lowlands and uplands had similar level of genetic diversity. These high levels of genetic variation are important for the conifers' ability to respond to selective pressures, such as changes in the environmental conditions, and decrease the risk from threats, such as pests and disease (Boys et al., 2005). Although the molecular diversity found is not representative for the adaptive variation, it may indicate that these populations harbour at least some variation to cope with environmental change.

The results also indicated that there was a deficiency of heterozygotes in all the four populations from the lowlands. For the uplands, there was a wide variation in the level of heterozygosity. These results should be interpreted with caution considering the small size of the populations analyzed. Thus, the differences between low and high land need to be validated with larger population sizes.

Table 1. - Isolated microsatellites from black spruce (Picea mariana) library, number of repeats and designed primers generating polymorphism useful for population genetic studies.

\begin{tabular}{|c|l|l|l|}
\hline $\begin{array}{c}\text { Microsatellite } \\
\text { sequence name }\end{array}$ & \multicolumn{1}{|c|}{$\begin{array}{c}\text { Number of } \\
\text { repeats }\end{array}$} & \multicolumn{1}{|c|}{ Primer pair sequences } & Size \\
\hline 2-6.35_SP6 & $(\mathrm{TA})_{4}(\mathrm{CA})_{33}$ & $\begin{array}{l}\text { F - GTAGATCCCTCAACAAGTG } \\
\text { R - CAAAGACCTGCAAAATAAA }\end{array}$ & 152 \\
\hline 2-7.7_SP6 & $(\mathrm{AT})_{7}(\mathrm{CA})_{23}$ & $\begin{array}{l}\text { F - GATGGTTGTGTGCTTATGT } \\
\text { R - CTTCCTTCAAATACATACATA }\end{array}$ & 165 \\
\hline 2-6.11_SP6 & $(\mathrm{AT})_{4}(\mathrm{GA})(\mathrm{CA})_{25}$ & $\begin{array}{l}\text { F - GGTGGTCATTTATATTGG } \\
\text { R - GTTCATCATAATTCACATG }\end{array}$ & 158 \\
\hline 2-4.39_SP6 & $(\mathrm{GT})_{16}(\mathrm{TT})(\mathrm{GT})_{8}$ & $\begin{array}{l}\text { F - GGAAACAGGCTAAAGCAC } \\
\text { R - GTGAAGTTGTTGCATCTA }\end{array}$ & 153 \\
\hline 2-3.7_SP6 & $(\mathrm{CA})_{24}(\mathrm{TA})(\mathrm{CA})_{2}$ & $\begin{array}{l}\text { F - GAAGCAAAGGGACATGTG } \\
\text { R - CATGGTACATGCACACAT }\end{array}$ & 133 \\
\hline 2-3.5_SP6 & $(\mathrm{CA})_{24}$ & $\begin{array}{l}\text { F - GGCTTAAAGGCATCACT } \\
\text { R - CCTCATGGGTTGCGGC }\end{array}$ & 146 \\
\hline $2-3.25 \_S P 6$ & $(\mathrm{CA})_{24}$ & $\begin{array}{l}\text { F - GTTAAAATTGCATTAGAAATAT } \\
\text { R - CCAGACCTTAAACCAACAA }\end{array}$ & 262 \\
\hline
\end{tabular}

1 gtt tct atc ccc att gta tga aca ata ggt gta acg tcc cca tcc act cga cag gtc ggg

61 caa cgc cac att gga aac atg ttt ctt ata tga cac cat ttt tgt gac ctt cca gac ctt

121 aaa cca aca agc cag gca aca tca cct cag aaa ata aca tgc tca agc atg aac aca cac

181 aca cac aca cac aca cac aca cac aca cac aca cac aca cat ata ttt cta atg caa ttt

241 taa cta gac att aac att $t$ tg $\mathrm{c}$

Figure 1. - Nucleotide sequence (262 bp) with microsatellite motifs registered in the GenBank under accession no. EF144154 (clone 2-3.25_SP6). The designed primer regions are underlined. 
Table 2. - Genetic diversity estimates for black spruce (Picea mariana) populations.

\begin{tabular}{lllllll}
\hline Population & $\mathrm{A}$ & $\mathrm{A}_{\mathrm{p}}$ & $\mathrm{H}_{\mathrm{O}}$ & $\mathrm{H}_{\mathrm{E}}$ & $\mathrm{I}$ & $\mathrm{F}_{\mathrm{IS}}$ \\
\hline $\begin{array}{l}\text { Site 1 } \\
\text { (wetland) }\end{array}$ & 5.67 & 5.33 & 0.482 & 0.619 & 1.333 & 0.201 \\
$\begin{array}{l}\text { Site 2 } \\
\text { (wetland) }\end{array}$ & 5.33 & 5.33 & 0.587 & 0.752 & 1.512 & 0.213 \\
$\begin{array}{l}\text { Site 3 } \\
\text { (dryland) }\end{array}$ & 5.67 & 5.67 & 0.652 & 0.768 & 1.572 & 0.152 \\
$\begin{array}{l}\text { Site 4 (dry } \\
\text { land) }\end{array}$ & 5.33 & 5.33 & 0.641 & 0.740 & 1.503 & 0.093 \\
$\begin{array}{l}\text { Site 5 } \\
\text { (wetland) }\end{array}$ & 6.33 & 6.33 & 0.648 & 0.729 & 1.532 & 0.102 \\
$\begin{array}{l}\text { Site 6 (dry } \\
\text { land) }\end{array}$ & 3.67 & 3.33 & 0.577 & 0.584 & 1.040 & -0.083 \\
$\begin{array}{l}\text { Site 7 (dry } \\
\text { land) }\end{array}$ & 6.00 & 6.00 & 0.559 & 0.744 & 1.541 & 0.241 \\
$\begin{array}{l}\text { Site 8 } \\
\text { (dryland) }\end{array}$ & 6.00 & 6.00 & 0.732 & 0.740 & 1.540 & -0.018 \\
$\begin{array}{l}\text { Site 9 (wet } \\
\text { land) }\end{array}$ & 5.67 & 5.67 & 0.425 & 0.772 & 1.585 & 0.441 \\
\hline A & & & & & & \\
\hline
\end{tabular}

$\mathrm{A}=$ mean allele number per locus; $\mathrm{A}_{\mathrm{p}}=$ mean number of polymorphic alleles per locus; $\mathrm{H}_{0}=$ observed heterozygosity; $\mathrm{H}_{\mathrm{E}}=$ expected heterozygosity (NEI, 1973); $\mathrm{I}=$ Shannon's information index; $\mathrm{F}_{\mathrm{IS}}=$ measure of heterozygote deficiency or excess.

The degree of population differentiation $\left(\mathrm{F}_{\mathrm{ST}}\right)$, was found to be 0.110 in the $P$. mariana population analyzed. This indicates that $11.0 \%$ of the total genetic diversity is attributed to differences among populations. This is lower than the $\mathrm{F}_{\mathrm{ST}}$ of 0.223 reported by WANG et al. (2005) in Picea asperata, 0.280 for Pinus resinosa (Boys et al., 2005), 0.172 for western white pine (Pinus monticola) and 0.190 for eastern white pine (Pinus strobus) (MeHEs et al., 2007). A low population differentiation is not an unusual feature in many conifer species, mostly due to long-distance pollen flow assisted by wind pollination. For instance, previous studies based on allozymes demonstrated low differentiation among northern populations of European Scots pine. In general, the levels of genetic diversity detected among populations of various widespread conifers species are usually found to be less than 10\% (Boys et al., 2005).

\section{Transferability of microsatellite markers}

In the present study, half of the microsatellite markers used in the polymorphism study was developed from white spruce genomic libraries. Both types of primer pairs, developed from Picea glauca and Picea mariana microsatellite libraries, produced polymorphic loci with Picea mariana DNA samples analyzed. The success of the cross-species amplification and the resolution of the microsatellite loci depend on evolutionary closeness of the taxa which are being analyzed (RAJORA et al., 2001). These findings are consistent with previous studies of transferability of microsatellite markers across related species (AMARASINGHE and CARLSON, 2002; HoDGETTS et al., 2001; RAJORA et al., 2001). It is the evolutionary conservation of the DNA flanking sequence that allows microsatellite primers developed from one species to be used in various related taxa (ECHT et al., 1999).

\section{Conclusion}

In the present study, new sets of primers pairs derived from a $P$. mariana (black spruce) genomic library were developed and characterized. These primers along with heterologous primers derived from $P$. glauca (white spruce) were used to determine the level of genetic variation in $P$. mariana populations from uplands and lowlands. High levels of heterozygosity were observed in all the nine populations analyzed. Therefore these primers are useful for detailed genetic study of $P$. mariana populations.

\section{Acknowledgements}

This work was supported by a discovery grant (to KKN) from the Natural Sciences and Engineering Research Council of Canada.

\section{Literature cited}

Amarasinghe, V. and J. E. CARLson (2002): The development of microsatellite DNA markers for genetic analysis in Douglas-fir. Can. J. For. Res. 32: 1904-1915.

Boys, J., M. CHERrY and S. DAYANANDAN (2005): Microsatellite analysis reveals genetically distinct populations of red pine (Pinus resinosa, Pinaceae). American Journal of Botany 92: 833-841.

Echt, C. S., P. MaY-MarquardT, M. Hseih and R. ZAHORECHAK (1986): Characterization of microsatellites markers in eastern white pine. Genome 39: 1102-1108.

Echt, C. S., P. May-Marquardt, M. Hsein and R. ZAHORECHAK (1996): Characterization of microsatellite markers in eastern white pine. Genome 39: 1102-1108. 
Echt, C. S. (1999): Use of microsatellite markers in management of conifer forest species. In: Douglas, G. C., ed. Strategies for improvement of forest trees. Dublin, Ireland: COFORD National Council for Forest Research and Development: 75-82.

Echt, C. S., G. G. Vendramin, C. D. Nelson and P. MaRQUARDT (1999): Microsatellite DNA as shared genetic markers among conifer species. Can. J. For. Res. 29: 365-371.

Edwards, K. J., J. H. A. Barker, A. DAly, C. Jones and A. KARP (1996): Microsatellite libraries enriched for several microsatellite sequences in plants. BioTechniques 20: 758-760.

GuPtA, A. K., B. Y. KANG, J. K. RoY and O. P. RAJORA (2005): Large scale development of selectively amplified microsatellite polymorphic loci (SAMPL) markers in spruce (Picea). Molecular Ecology notes 5 (3): 481.

Hamilton, M. B., E. L. Pincus, A. Di Fiore and R. FleiSHER (1999): Universal linker and ligation procedures for construction of genomic DNA libraries enriched for microsatellites. BioTechniques 27: 500-507.

Hodgetts, R. B., M. A. Aleksiuk, A. Brown, C. Clarke, E. MacDonald, S. Nadeem and D. Khasa (2001): Development of microsatellite markers for white spruce (Picea glauca) and related species. Theor. Appl. Genet. 102: $1252-1258$.

LIU, K. J. and S. V. Muse (2005): PowerMarker: an integrated analysis environment for genetic marker analysis. Bioinformatics 21: 2128-2129.

Mehes, M., K. K. Nkongolo and P. Michael (2007): Genetic analysis of Pinus monticola and Pinus strobes using microsatellites. Poster presented at the joint annual meeting of the Canadian Genetic Society of
Canada and Canadian Fly Society in Montreal (Qc), June 18-22.

Nkongolo, K. K., P. Michael and T. Demers (2005): Application of ISSR, RAPD, and cytological markers to the certification of Picea mariana, P. glauca, and $P$. engelmannii trees and their putative hybrids. Genome 48: 302-311.

Pfeiffer, A., A. M. Olvieri and M. Morgante (1997): Identification and characterization of microsatellites in Norway spruce (Picea abies K.). Genome 40: 411-419.

RAJORA, O. P., M. H. RHAMAN, S. DAYANANDAN and A. Mosseler (2001): Isolation, characterization, inheritance and linkage of microsatellite DNA markers in white spruce and their usefulness in other spruce species. Mol. Gen. Genet. 264: 871-882.

Ranger, M., K. VAndeligt, P. Michael, K. K. Nkongolo and P. BECKETT (2007): Microsatellite and ISSR analysis of Pinus banksiana and Pinus resinosa from metal contaminated areas in the Greater Sudbury region. Paper presented at the Mining and Environment IV Conference in Sudbury (ON), October 19-27.

Scotti, I., G. P. Paglia, F. Magni and M. Morgante (2002): Efficient development of dinucleotide microsatellite markers in Norway spruce (Picea abies Karst.) through dot-blot selection. Theor. Appl. Genet. 104: 1035-1041.

Wang, Y., J. Luo, X. Xue, H. Korpelainen and C. Li (2005): Diversity of microsatellite markers in the populations of Picea asparta originating from the mountains of China. Plant Science 168: 707-714.

YEH, F. C. and T. J. B. BoYLE (1997): Population genetic analysis of co-dominant and dominant markers and quantitative traits. Belg. J. Bot. 129: 157.

\title{
Phenotypic Selection of Calycophyllum spruceanum on Farms in the Peruvian Amazon: Evaluating a Low-Intensity Selection Strategy
}

\author{
By John C. Weber ${ }^{\left.1,3,{ }^{*}\right)}$, Carmen Sotelo Montes ${ }^{1,3)}$, Julio Ugarte ${ }^{1)}$ and Tony Simons ${ }^{2)}$
}

(Received $4^{\text {th }}$ August 2008)

\begin{abstract}
A low-intensity selection strategy was recommended for timber trees in the Peruvian Amazon to maintain genetic variation on farms and produce modest gains in tree growth. The effectiveness of this strategy was evaluated using Calycophyllum spruceanum. Farmers selected 66 mother trees of different ages on farms in

\footnotetext{
1) World Agroforestry Centre (ICRAF), CIP, Apartado Postal 1558, Lima 12, Peru.

2) World Agroforestry Centre (ICRAF), P.O. Box 30677-00100, Nairobi, Kenya.

${ }^{3}$ ) World Agroforestry Centre (ICRAF), West and Central Africa Regional Office, B.P. E5118, Bamako, Mali.

*) Author for correspondence: John C. WeBER. Telephone: (223) 2223375, fax: (223) 2228683. E-Mail: johncrweber@aol.com
}

seven locations ( $\sim 20 \%$ of all trees in the locations) in one watershed, based on a visual assessment of growth, form and external disease symptoms. Another 66 mother trees were chosen at random. Tree height, stem diameter, stem bifurcations and mortality of progeny of the selected and random groups of mother trees were evaluated at 15, 26 and 38 months in a provenance/progeny test located on farms in the same watershed. Height was significantly greater $(10 \%)$ in the selected group at 15 months, but it did not differ significantly between the selected and random groups at 26 and 38 months. There were no significant differences in diameter, bifurcations and mortality between the groups. There was significant variation in height and diameter at all measurement ages due to families, and results suggested that variation in bifurcations and mortality due to families was also significant. Based on approximate $95 \%$ confidence 